\title{
Agro-Industrial Complex of the Russian Arctic: Research Contribution to the Value Added Areas
}

\author{
Ekaterina Zakharchuk ${ }^{*}$ \\ Institute of Economics, Ural Branch of the Russian Academy of Sciences, Moskovskaya Str., 29, \\ Yekaterinburg, Russia
}

\begin{abstract}
The article deals with the problems of assessing the contribution of the agro-industrial complex to the economy of the Arctic territories. An approach to the definition of the notion "agro-industrial complex" from the point of view of the System of National Accounts is highlighted. The author proposes a method of calculating the value added of economic activities at the municipal level. On this basis, formed a database of wages of all municipalities of the Arctic region of Russia. The author calculated the contribution of agro-industrial complex in gross value added Arctic municipalities in the context of the Russian Federation. The results obtained allow us to highlight the importance of the agro-industrial complex in the economy of municipalities in the Arctic zone of Russia. The agro-industrial complex is of the greatest importance in the economy of the Anabar national region of the Republic of Yakutia and the city of Murmansk. The calculations showed that the added value of the agroindustrial complex for the whole Arctic territories of Russia is 55,821.78 million rubles, and its contribution to the total value added is $1.56 \%$.
\end{abstract}

\section{Introduction}

The operation of the agro-industrial complex in the Arctic zone of the Russian Federation is traditionally limited by harsh natural conditions. Extremely low temperatures in winter and summer, high operating costs, competition with domestic and foreign suppliers determine the narrow areas of activity for the production of food in the Arctic. At the same time, the unique conditions of the Russian polar region, the vast expanses of untouched natural environment allow to develop certain types of agricultural activities, are not available for other areas. For some Arctic territories, this activity is essential in the formation of added value, especially in the absence of industrial production.

In the scientific literature, an issue of food production in the Arctic is usually considered through traditional types of farming: reindeer husbandry, fishing, gathering wild plants, etc. Loginov VG, Ignatieva MN, Balashenko VV [1] identified the problems of development of traditional nature management (the main branches of which are represented by reindeer husbandry and fishing) in the territories of active industrial and transport development of

\footnotetext{
* Corresponding author: zakhartchouk@mail.ru
} 
the North and the Arctic. They evaluated the transformation of agro-industrial complex and the impact on the livelihoods of indigenous peoples. Reindeer herding is one of the main traditional activities of the indigenous ethnic groups, seen in different directions. For example, Raitio K., Allard C., Lawrence R. [2] investigates the impact of the extractive industry on reindeer husbandry in terms of current Swedish legislation. They analyze the possibility of the influence of the Sami reindeer herders on the issuance of permits for the mines, the authors highlight the existing legal imperfections in this area. Klokov KV [3], in his research, studies reindeer husbandry in terms of changes in their numbers in the regional context. He found that the growth of the reindeer population is observed in those regions of the Russian Arctic, where the informal economic environment is developed. Antonov EV, Litvinenko TV, Nuvano, VN [4] identified the factors influencing the reindeer population at different spatial levels: international, national, regional. The authors have established the reasons for the geographical shifts in domestic reindeer husbandry.

Fishing is another equally important area in the economic activity of the aboriginal population in the Arctic territories. Hodgson EE, Hovel RA, Ward EJ, Lord S., Moore JW in their work [5] assess the vulnerability of arctic fish species, wildlife and indigenous peoples to climate change. Popova NV, Abramov AF, Markova LN [6] evaluated the effect of anthropogenic pollution of rivers and lakes on the population of fish resources in Yakutia. The paper notes that the socio-economic and climatic factors have a negative impact on the fish catch in the region, as well as the presence of toxic metals in the fish flesh. Nuutila J. [7] raises the question that, along with the study of agricultural and environmental problems of the Arctic territories, it is necessary to pay attention to the development of the organic food sector, based on interdisciplinary and holistic research. The possibilities of developing this direction are considered on the example of Finland.

Namzalov BC.B, Afanasyeva EF, Taisaev TT [8] analyzed the socio-economic situation of the Evenks in the Barguzin Valley. And perspectives of development of the Norman forms of livestock, which is adapted to harsh climatic conditions. Based on the study of the foreign experience of the northern countries and the generalization of existing practices on the organization of agriculture, Ivanov VA, Ivanova EV [9] proposed recommendations for its organization in Russia. They mark the most promising Scandinavian way of farming, mainly in Finland. Vlasova TK, Kaplin NS, Volkov SG [10] are engaged in studying the interaction of traditional and industrial nature. The authors identified the main approaches and mechanisms for resolving conflict situations arising between logging companies and indigenous communities.

As can be seen from the review of scientific articles, studies the impact of agriculture and fisheries in the economy of the territory is considered negligible, it focuses on sectoral problems of development of the traditional economy.

Therefore, the purpose of this study is to determine the contribution of the agroindustrial complex to the added value of the Arctic territories of the Russian Federation, and to highlight the features of its development in certain economic regions.

\section{Methods}

In modern literature there are many interpretations of the term "agro-industrial complex". In the traditional sense, the agro-industrial complex means a certain set of economic agents engaged in the production of agricultural goods. For example, in [11] is a considerable range of views on the understanding of that term. From a complex of industries involved in the production of agricultural products to an economic system that combines various fields of activity. The identification of a number of interrelated industries in the agro-industrial complex has become canonical in the research. Firstly, it is the company agriculture, directly producing goods (agriculture and livestock). Second, the business entities that 
provides various complex materials (by different techniques to fertilizers). Thirdly, enterprises for the processing of agricultural products, as well as storage and delivery to the consumer. From these points of view, the agro-industrial complex is considered as an intersectoral one, including specialized enterprises for the production, maintenance and transportation of agricultural products.

In this study, we propose to consider the agricultural sector in the narrower sense. Determining the impact of this complex on the economy of the Arctic territories is impossible without the use of official statistics. Therefore, for this work, we propose to consider the agro-industrial complex on the basis of identifying types of economic activities.

After the transition of the Russian statistical system on the methodology of the System of National Accounts (SNA) [12], to display the sectoral focus of the economy in Russia has been applied Classification of Economic Activities. Section A "Agriculture, hunting and forestry" has been introduced in this classifier for enterprises engaged in the production of food products. Thus, the statistical system refers to the agro-industrial complex only the so-called "clean" economic establishments directly involved in the production of agricultural products. And besides under "Agriculture, hunting and rendering of services in these spheres" in this section are also included companies in "Forestry and rendering of services in this area". Apparently, this assignment is due to historical traditions, considering logging as one of the types of semi manufactures. In 2016, in connection with the development of the System of National Accounts, a new classifier of types of economic activities (second version) was introduced in Russia. In this classifier, there have been significant changes both in the coding and the filling of activities. Section A was supplemented with Section B "Fishing, fish farming" of the old classifier, and became known as "Agriculture, forestry, hunting, fishing and fish farming". Thus, in the Russian statistical system arose a separate activity, reflecting the production of food and related industries. In the new classification also included a number of ancillary activities, as well as the provision of agricultural services. It is also clarified that forestry related activities only on the harvesting of round wood (without treatment).

In addition to this, the Russian Government has identified a list of products related to agricultural production (Decree of July 25, $2006 \mathrm{~N} \mathrm{458).} \mathrm{It} \mathrm{provides} \mathrm{a} \mathrm{list} \mathrm{of} \mathrm{products}$ classified as primary processed products made from agricultural raw materials, in which fish and fish products are present. Based on this, it can be argued with rather high confidence that the use of data for sections A and B (old classification) or section A (new classification) reflects the contribution of the agro-industrial complex to the structure of the economy of the territories.

Another research issue is the selection of the object of research, that is, the Arctic territories themselves. In this article, we will not delve into the history and problems of the issue; discussions on this matter are presented in works $[13,14]$. We only note that we have formed the author's list of the Arctic territories, based on the territorial (along the borders of the Arctic Circle) and economic (place of employment of the population) principles of attribution [15]. This list includes entire subjects of the federation, for example, the Murmansk Region, the Nenets Autonomous Region. So are municipalities within regions, depending on the criteria developed. For example, the Krasnoyarsk region is located on a large territory from the coast of the Kara Sea to the almost northern border with Mongolia. The Arctic territories in its composition occupy a fairly significant area, but in terms of territorial division, only 4 out of 61 municipalities belong to the Polar Territories. Roughly the same situation has developed in Yakutia, the Yamalo-Nenets Autonomous Okrug, the Komi Republic and the Chukotka Autonomous Okrug.

Since the classification of our Arctic territories includes both the regions as a whole, and a group of municipalities, the authors proposed a method of determining the value 
added at the level of municipalities, as the main object of study. The method, described in detail in [16], is as follows. As a basis for assessing the value added of a municipality, data on wages by type of economic activity are used. Such information is in the public domain of the Russian statistical agency. Then, we use regional tables of income generation by wages, production taxes and gross mixed income. And distributes value-added in the region between the municipalities according to the following formula [16]:

$$
\mathrm{GVA}_{i, m u, y}=\sum_{m u=1}^{n}\left(\frac{\mathrm{GVA}_{i, \text { reg.,y }}}{S F_{i, \text { reg.,y }}} \times S F_{i, m u, y}\right) / 1000, \text { if } \sum_{m u=1}^{N} \mathrm{GVA}_{i, m u, y}=\mathrm{GVA}_{i, r e g, y}
$$

where $\mathrm{GVA}_{i, m u, y}$ - value-added of a municipality; $\mathrm{GVA}_{i, \text { reg,y }}$ - value-added of a type of economic activity in a region; $S F_{i, r e g, y}$ - salary fund by economic activity table of income in the region; $S F_{i, m u, y}$ - salary fund by economic activity table of income in municipality.

The method used depends rather strongly on the data integrity of municipalities. In previous studies we have carried out such an assessment. We concluded that Russian statistics of this kind, although not ideal, can be used in calculations. Another problem in the availability of information is the income account of the Gross Regional Product of the regions, which is not available in the public domain. However, upon request to the territorial bodies of statistics, this information is subject to disclosure.

Using this approach, we get a table form of added value in the region in the context of both the territories and economic activities. Based on this, we can assess the impact of the agro-industrial complex on the formation of added value in the Arctic territories.

\section{Results and Discussion}

In determining the share of the agricultural sector in the economy of the Arctic territories, it is first necessary to consider the overall impact of agriculture on the economy of the Arctic regions. For this, we used data from the income generation account of the Gross Regional Product for the regions under study (Table 1).

Table 1. The contribution of agro-industrial complex in gross value added (GVA) of the Arctic regions, in 2016, mln. Rub. and \%

\begin{tabular}{|l|c|c|c|c|}
\hline \multirow{2}{*}{ Arctic Regions } & \multirow{2}{*}{ GVA total } & \multicolumn{2}{c|}{ GVA agro-industrial complex } & \multirow{2}{*}{$\begin{array}{c}\text { Total in \% to } \\
\text { GVA of region }\end{array}$} \\
\cline { 3 - 4 } Murmansk region & 425831,2 & 1218,2 & 47929,2 & $11,54 \%$ \\
\hline Komi Republic & 546895,3 & 10408,5 & 95,5 & $1,92 \%$ \\
\hline $\begin{array}{l}\text { Nenets Autonomous } \\
\text { Okrug }\end{array}$ & 255496,6 & 731,9 & 1553,7 & $0,89 \%$ \\
\hline $\begin{array}{l}\text { Yamalo-Nenets } \\
\text { Autonomous Okrug }\end{array}$ & 1963870,5 & 2278,1 & 155,3 & $0,12 \%$ \\
\hline Krasnoyarsk region & 1767908,2 & 68486,6 & 491,6 & $3,90 \%$ \\
\hline $\begin{array}{l}\text { Republic of Yakutia }- \\
\text { Sakha }\end{array}$ & 868606,9 & 15038,2 & 249,1 & $1,76 \%$ \\
\hline $\begin{array}{l}\text { Chukotka Autonomous } \\
\text { Okrug }\end{array}$ & 66146,8 & 304,4 & 130,3 & $0,66 \%$ \\
\hline Total & 5894755,5 & 88057,4 & 50604,7 & $2,35 \%$ \\
\hline
\end{tabular}

As can be seen from the table, in the regional value added on average across the regions of Russia, the share of the agro-industrial complex in 2016 was $2.35 \%$. The largest 
contribution was made by agriculture, approximately $63.5 \%$ of the whole agricultural sector, the rest had to fish. Among the regions allocated Murmansk (all part of the Arctic zone), which holds about a third of all agricultural production in the Arctic. The lowest value of the agro-industrial complex is observed in the Yamalo-Nenets Autonomous Okrug $(0.12 \%)$ and the Chukotka Autonomous Okrug (0.66\%). Despite this, in absolute terms, the difference between the regions is colossal. Yamal produces agricultural products worth almost 2.5 billion rubles, while in Chukotka this figure is less than 0.5 billion rubles. It should be noted that according to the income generation accounts of the Yamalo-Nenets Autonomous Okrug, negative value added was formed in the fishing division. With 155.3 million rubles of added value of section $\mathrm{B}, 801.8$ million rubles were spent on wages. This may indicate two options: either the fishing industry in 2016 was deeply unprofitable, or it was subsidized from external sources. Sufficient weight of agriculture in absolute terms is observed in the Komi Republic and the Krasnoyarsk Territory. However, as we noted earlier, in these regions, only a small number of municipalities are attributed to the Arctic, and what impact they have on the agro-industrial complex of the region, we will consider further.

As a preliminary analysis of our calculations showed, not all territories have data on accrued wages in sections A and B. The fact is that the Russian statistical system records only officially registered enterprises in these sectors, without making additional calculations for personal consumption. These include growing vegetables and fruits on private land plots, raising livestock for personal consumption, and fishing for households. Also, some part can be used in monetary exchange, based on payment schemes hidden from state bodies (commodity exchange, cash).

Therefore, in this study we use only the "visible" part of the agro-industrial complex, that is, which is involved in the officially registered economic turnover. We believe that for the conditions of the Arctic, and in the presence of vast untouched territories, the role of agriculture and fishing in the considered municipalities is much greater. Unaccounted for may be such activities of the agro-industrial complex as picking wild berries, nuts and mushrooms, procurement of medicinal plants, production of semi-finished products from fish. How this activity relates to official data, the answer to this question requires special research using field methods. Based on the foregoing, Table 2 presents the results of calculating value added for the agro-industrial complex in the context of municipalities in the Arctic. Municipalities that do not register agricultural and fishing activities are not represented in the table in order to reduce data.

Table 2. The contribution of agriculture in gross value added (GVA) of the Arctic municipalities (MU) in the context of the subjects of the Russian Federation, in 2016, mln. Rub. and \%

\begin{tabular}{|c|c|c|c|c|c|}
\hline \multirow{2}{*}{$\begin{array}{l}\text { Municipalities } \\
\text { (districts) }\end{array}$} & \multirow{2}{*}{$\begin{array}{c}\text { Total GVA } \\
\text { MU }\end{array}$} & \multicolumn{2}{|c|}{$\begin{array}{l}\text { GVA agro-industrial } \\
\text { complex }\end{array}$} & \multirow{2}{*}{$\begin{array}{c}\text { Total in } \\
\% \text { to } \\
\text { GVA } \\
\text { MU }\end{array}$} & \multirow{2}{*}{$\begin{array}{l}\text { In } \% \text { of the } \\
\text { region's } \\
\text { agricultural } \\
\text { complex }\end{array}$} \\
\hline & & Section A & Section B & & \\
\hline \multicolumn{6}{|c|}{ Murmansk region } \\
\hline Kol'skiy & 17073,7 & 727,7 & 3331,0 & $23,8 \%$ & $8,3 \%$ \\
\hline Kandalakshskiy & 16978,0 & 75,9 & 0,0 & $0,4 \%$ & $0,2 \%$ \\
\hline Lovozerskiy & 2432,7 & 181,6 & 0,0 & $7,5 \%$ & $0,4 \%$ \\
\hline Terskiy & 1191,4 & 136,4 & 0,0 & $11,5 \%$ & $0,3 \%$ \\
\hline Murmansk city & 205058,6 & 96,6 & 44598,2 & $21,8 \%$ & $90,9 \%$ \\
\hline \multicolumn{6}{|c|}{ Nenets Autonomous Okrug } \\
\hline Zapolyarny & 196978,4 & 387,5 & 344,3 & $0,4 \%$ & $32,0 \%$ \\
\hline Naryan-Mar city & 57710,3 & 884,1 & 669,6 & $2,7 \%$ & $68,0 \%$ \\
\hline
\end{tabular}




\begin{tabular}{|c|c|c|c|c|c|}
\hline \multicolumn{7}{|c|}{ Yamalo-Nenets Autonomous Okrug } \\
\hline Nadymskiy & 303011,0 & 321,8 & 0,0 & $0,1 \%$ & $13,2 \%$ \\
\hline Priural'skiy & 15286,2 & 161,6 & 0,0 & $1,1 \%$ & $6,6 \%$ \\
\hline Purovskiy & 435123,3 & 384,9 & 62,3 & $0,1 \%$ & $18,4 \%$ \\
\hline Yamal'skiy & 253249,2 & 429,2 & 0,0 & $0,2 \%$ & $17,6 \%$ \\
\hline Tazovskiy & 128218,4 & 209,3 & 93,0 & $0,2 \%$ & $12,4 \%$ \\
\hline Salekhard city & 66271,4 & 216,4 & 0,0 & $0,3 \%$ & $8,9 \%$ \\
\hline \multicolumn{7}{|c|}{ Krasnoyarsk region } \\
\hline Taymyrskiy Dolgano- & 32910,5 & 282,5 & 0,0 & $0,9 \%$ & $0,4 \%$ \\
\hline Nenetskiy & 32667,5 & 456,2 & 0,0 & $1,4 \%$ & $0,7 \%$ \\
\hline Evenkiyskiy & Republic of Yakutia - Sakha \\
\hline Anabarskiy & 823,6 & 257,8 & 0,0 & $31,3 \%$ & $1,7 \%$ \\
\hline Bulunskiy & 3223,0 & 224,1 & 207,6 & $13,4 \%$ & $2,8 \%$ \\
\hline Verkhoyanskiy & 3772,6 & 68,2 & 0,0 & $1,8 \%$ & $0,4 \%$ \\
\hline Momskiy & 1406,4 & 93,9 & 0,0 & $6,7 \%$ & $0,6 \%$ \\
\hline Nizhnekolymskiy & 2203,7 & 301,8 & 0,0 & $13,7 \%$ & $2,0 \%$ \\
\hline Olenekskiy & 2459,0 & 181,9 & 0,0 & $7,4 \%$ & $1,2 \%$ \\
\hline Srednekolymskiy & 1723,4 & 212,6 & 0,0 & $12,3 \%$ & $1,4 \%$ \\
\hline Ust'-Yanskiy & 3819,1 & 0,0 & 41,6 & $1,1 \%$ & $0,3 \%$ \\
\hline Chukotka Autonomous Okrug & \\
\hline Bilibinskiy & 8799,4 & 54,3 & 0,0 & $0,6 \%$ & $12,5 \%$ \\
\hline Iul'tinskiy & 2687,6 & 82,9 & 0,0 & $3,1 \%$ & $19,1 \%$ \\
\hline Chukotskiy & 1204,5 & 45,0 & 0,0 & $3,7 \%$ & $10,4 \%$ \\
\hline
\end{tabular}

In the Arctic municipalities of the Komi Republic, activities in the branches of the agroindustrial complex are not registered. In the Murmansk region, the greatest influence of the agro-industrial complex on the economy is recorded in the Kola municipal district $(23.8 \%)$. Despite the significant volume of agricultural products manufactured (more than $90 \%$ of the entire region), the importance of agricultural industries for the city of Murmansk is approximately the same $(21.8 \%)$. For the rest of the Murmansk region agro complex does not play such a high value. In the Nenets Autonomous Okrug, which consists of two municipalities, the city of Naryan-Mar accounts for more than two thirds of the entire agroindustrial complex and $2.7 \%$ of the added value of the municipality. In the Arctic municipalities of the Yamal-Nenets Autonomous Okrug, the share of the added value of the agro-industrial sector in the economy exceeds $1 \%$ only in the Priuralsky municipal region. In the rest of the municipalities of Yamal, the agricultural complex takes on average $0.2 \%$ of the added value. Fisheries are officially registered in two municipalities, but subsidies to the industry have resulted in little added value to the fishery. In general, the Arctic territories of Yamal account for $77.2 \%$ of the added value of the agro-industrial complex of the Okrug. The influence of agriculture on the development of the Arctic territories of Krasnoyarsk region is also insignificant, about $1 \%$. Slightly more in the Evenk municipal district (1.4\%), slightly less in the Taimyr (0.9\%). All Arctic territory of the Republic of Yakutia form only $10.4 \%$ of agro products Sahi. However, in some Arctic municipalities, agricultural production plays a significant role in the economy. For example, in the Anabar National Municipal District, the agro-industrial complex occupies 31.3\% of the total added value of the territory. In three other Arctic municipalities of Yakutia, the share of the agro- 
industrial sector exceeds $10 \%$, which is also relatively high. In the Chukotka Autonomous Okrug, the Arctic territories form more than $40 \%$ of all products of the agro-industrial complex. In 3 out of 4 Arctic territories, the share of value added in sections A and B ranges from 10 to $20 \%$, which predetermines the significant role of the agro-industrial complex.

In general, for the Arctic territories of the Russian Federation, using the GVA calculations in an earlier work [16], it can be argued that out of 3,584,275.86 million rubles of added value, the agro-industrial complex accounts for 55,821.78 million rubles, or $1.56 \%$. This is extremely insufficient, given the potential of the Arctic territories.

\section{Conclusion}

As a result of the study we can make a number of key findings.

1. Despite the weak data on the statistics of municipalities, in the Russian realities, it is possible to use methods for highlighting the contribution of any industry to the added value of territories.

2. In general, the influence of the agro-industrial sector in the added value of the Arctic municipalities is insignificant. This is due to the specific conditions of farming and fishing in the Arctic.

3. In some municipalities of the Arctic, in the absence of a large industrial sector, the share of the agro-industrial sector is significant. This is especially evident in the municipalities of the Murmansk region and the Republic of Yakutia-Sakha.

4. In many municipalities the Arctic zone there is no information on the activities of the agro-industrial complex. In our opinion, this is due to the lack of accounting operations for personal consumption of households.

5. The largest producer of agro-industrial products is the city of Murmansk, where industrial fishing of the entire northern coast of Russia is displayed.

In general, the potential of the Arctic in the agricultural sector is not completely open, the state and the professionals need to pay attention to the increasing support of the industry. At the same time, for scientists engaged in agriculture in the Arctic zone, our findings and conclusions may be interesting. Especially from the point of view of the influence of the agro-industrial complex on individual municipalities, using our data for further research in the direction.

\section{Acknowledgements}

The study was sponsored by RFBR Project number 18-010-01007 A "Financial flows of the Arctic: the formation, distribution and use of value-added in terms of industrial development of new spaces".

\section{References}

1. V.G. Loginov, M.N. Ignatyeva, \& V.V. Balashenko, Economy of Region, 14(3), 896913 (2018) DOI: 10.17059/2018-3-15

2. K. Raitio, C. Allard, R. Lawrence, Mineral extraction in Swedish Sápmi: The regulatory gap between Samirights and Sweden's mining permitting practices Land Use Policy, 99, 105001 (2020) DOI:10.1016/j.landusepol.2020.105001

3. K.B. Klokov, IOP Conf. Ser.: Earth Environ. Sci., 539, 012180 (2020) doi: $10.1088 / 1755-1315 / 539 / 1 / 012180$ 
4. E.V. Antonov, T.V. Litvinenko and V.N. Nuvano, Regional Research of Russia, 91 53-65 (2019) doi: 10.1134/S2079970519010027

5. E.E. Hodgson, R.A. Hovel, E.J. Ward, S. Lord, J.W. Moore, Biological Conservation, 248, 108685 (2020) DOI: 10.1016/j.biocon.2020.108685

6. N.V. Popova, A.F. Abramov, \& L.N. Markova, Open Agriculture, 5(1), 213-218 (2020) doi: https://doi.org/10.1515/opag-2020-0022

7. J. Nuutila, Org. Agr. 9, 165-173 (2019) https://doi.org/10.1007/s13165-018-0220-3

8. B-Ts. B. Namzalov, E.F. Afanasieva, T.T. Taisaev, Inner Asian nature, 2, 49-61 (2017) doi: 10.18101/2542-0623-2017-2-49-61

9. V.A. Ivanov, E.V. Ivanova, Arctic: ecology and economy, 2(26), 117-130 (2017) DOI: 10.25283/2223-4594-2017-2-117-130 (In Russian)

10. T.K. Vlasova, N.S. Kaplin, S.G. Volkov, Biosphere economy: theory and practice, 1, 5-16 (2018)

11. S.P. Suvorova, E.I. Toslunova, International research journal, 4, 116-120, (2016) DOI: 10.18454/IRJ.2016.46.135

12. SNA - System of National Accounts 2008, released by the United Nations, the European Commission, the International Monetary Fund, the Organization for Economic Cooperation and Development, and the World Bank, New York, 2009

13. A.I. Tatarkin, Russian Arctic: Modern paradigm of develolment ( $\mathrm{SPb}$.: Nestor-Istoriya, 2014)

14. V.N. Lazhentsev, Economy of region, 14(2), 353-365 (2018) DOI: 10.17059/2018-22.

15. A.I. Tatarkin, E.A. Zakharchuk \& A.F. Pasynkov, Russia's Arctic territories: formation of statistical areas and justification of financial development's opportunities (Ekaterinburg, 2015)

16. E.A. Zakharchuk, Economy of Region, 15(2), 391-408 (2019) doi 10.17059/2019-2-7 